\title{
Comparative Study on Copyright Exception for Teaching Purposes: Australia, Malaysia and the United Kingdom
}

\author{
Ratnaria Wahid \& Ida Madieha Abdul Ghani Azmi
}

\begin{abstract}
While education is considered a basic human right, the copyright system however seems to hamper public access to information and knowledge. This is especially so when information that largely comes from developed countries are used as commodities that have to be bought by developing countries. This paper compares the international and national laws in Malaysia, United Kingdom and Australia on the copyright exceptions to materials used for teaching purposes. It analyzes the different ways countries manage and balance between copyright owners and copyright users' interest and shows that in many circumstances, copyright owners are over-protected by national copyright systems although this is not required by international copyright law. This paper also shows that international treaties governing copyright law do allow some flexibility for member countries to implement copyright systems based on their own needs and circumstances but such opportunity is not fully utilized by member countries for the benefit of the public.
\end{abstract}

Keywords: International copyright law, education, United Kingdom, Australia, Malaysia.

\section{Introduction}

Despite the rapid development in information communication technology, the problem of inequitable knowledge acquisition or denial of opportunities to acquire, use and share knowledge still occurs. This was emphasized by Mr. Koichiro Matsuura (2009), the Director General of UNESCO in his addressing speech at the UNESCO Future Forum on Knowledge Acquisition and Sharing when he stated:

"Never before in human history has so much information been so readily available to so many. In an increasingly connected global community, the ability to access information and transform it into meaningful and useful knowledge is a key driver of sustainable social and economic development. Yet, knowledge acquisition and sharing is still far from equitable. Huge numbers of people, particularly in developing countries but also marginalized groups elsewhere, are denied the opportunities to acquire, use and share knowledge in this way". 
One of the factors that contribute to the problem of knowledge acquisition and sharing is the system brought about by copyright law. The Berkman Center for Internet and Society, conducting studies examining the relationship between copyright law and education, found that the copyright law provisions concerning the educational use of copyrighted material, as well as the business and institutional structures, are among the most important obstacles to realizing the potential of digital technology in education (Fisher et al., 2006). The 2003, United Nations Development Programme Report also reported that the cost of copyright protected educational material and software increased due to the Trade Related Intellectual Property (TRIPS) agreement and that it is possible for copyright owners to control and limit access to information under the 1996 WIPO Treaties arrangement on technological protection measures.

Moreover, the benefits from Information and Communication Technologies (ICT) in higher education are also unevenly distributed around the world and ICT was used as a tool to concentrate the ownership of publishers, databases, and other key resources in the hands of the strongest universities and some multinational companies, located almost exclusively in the developed world (Altbach, Reisberg, \& Rumbley, 2009). Furthermore, numerous regulatory, administrative, technical, and logistical challenges further hamper the use and deployment of ICT in accessing resources for education (Altbach, Reisberg, \& Rumbley, 2009), thereby putting developing countries at a significant disadvantage. The uneven distribution of human capital and funds inadvertently allows some nations to take full advantage of the new opportunities while other nations risk lagging further behind to the extent of jeopardizing the right of man to have access to knowledge and education.

\section{Right to Education}

Every man, woman, youth and child has the human right to education, training and information. This is a basic human right explicitly set out in the Universal Declaration of Human Rights, Article 26 (1) which reads as follows:
"Everyone has the right to education. Education shall be free, at least in the elementary and fundamental stages. Elementary education shall be compulsory. Technical and professional education shall be made generally available and higher education shall be equally accessible to all on the basis of merit... Education shall be directed to the full development of the human personality and to the strengthening of respect for human rights and fundamental freedoms. It shall promote understanding, tolerance and friendship among ... racial or religious groups...."

Although the Universal Declaration of Human Rights is merely aspirational or advisory in nature and not a binding treaty, it has gradually gained importance, acquiring the status of customary international law. 
A specific treaty article that imposes legally binding obligations on member states that become contracting parties to it, particularly the International Covenant on Economic, Social and Cultural Rights also recognized the right to education. Its Article 13 states as follows:

"The States Parties ... recognize the right of everyone to education.... Education shall enable all persons to participate effectively in a free society, promote understanding, tolerance and friendship among ... racial, ethnic or religious groups.... Primary education shall be compulsory and available free to all... Secondary education ... including technical and vocational secondary education, shall be made generally available and accessible to all.... Higher education shall be made equally accessible to all...."

Other provisions supporting the right to education are also enshrined in the Convention on the Elimination of All Forms of Discrimination Against Women, (Articles 10 and 14), Convention on the Elimination of All Forms of Racial Discrimination (Article 5), Convention on the Rights of the Child (Articles 28 and 29) and the Convention against Discrimination in Education (Articles 3, 4, and 5).

\section{Educational Exception in Copyright Law}

The importance of educational activities is also recognized in the realm of international copyright law. Briefly, copyright is an exclusive right allowing copyright owner to prevent anyone from copying or using their work. Once a work has met the criteria for protection, authors (creators) are automatically given a bundle of rights to reproduce or authorize others to do various acts restricted by the copyright law, including, to reproduce or copy, to publish, to rent out or lend, to perform, show as well as to broadcast the work to the public (Garnett, James, \& Davies, 1999).

Works protected by copyright are generally the expression of creative authorship which includes original artistic, dramatic, literary, musical works, sound recordings, films (and videos), broadcasts (including cable and satellite broadcasts) and the typographical arrangements of published editions of a literary, dramatic or musical work which are increasingly used for educational purposes. These works may either be published or unpublished or in electronic format. Thus, letters, e-mail messages, works included in an electronic database (CD-ROMs) and material on websites are also protected (Sandy, 2004).

The standard term of copyright protection lasts for the author's lifetime plus 70 years from the end of the year in which he died (or from the end of the year in which it was made in the case of films and broadcasts), it can be assigned or transmitted on death. The principal remedies for breach of copyright (known as piracy) are an action for damages and account 
of profits or an injunction. It is a criminal offence knowingly to make or deal in articles that infringe a copyright.

As early as in the first edition of the Berne Convention, the most important international agreement governing copyright and related rights, has readily acknowledged copyright exception for the purpose of education. Article 8 of the Berne Act 1886, state as follows:

"With regard to the right to make lawful borrowings from literary or artistic works for publications intended for education or of scientific character, or for chrestomathies, the effect of the legislation of the countries of the Union and of special arrangements existing or to be concluded between them is reserved".

This provision reserve the right to member countries to allow public to use literary or artistic works without any need for permission or payment to the copyright owner if the use is for the purpose of education. This provision however raises several opposition and disagreement from several countries. Some countries opt for a stricter provision that will protect authors' rights while other countries prefer a lenient provision for education purposes. Netherlands for instance viewed that "production of school text books was now a commercial business and authors should not be deprived of their rightful share in the business" (WIPO, 1971,p.862). In contrast, some countries particularly developing countries such as India and Rumania, proposed that the exceptions be broadened so as to make it possible to use works for educational purposes and to accrue benefits from the production of textbook due to the essential need for countries to improve their educational systems.

After several years of negotiations and discussions, the current Article 10(2) of the Berne Convention for the Protection of Literary and Artistic Works 1886 specifically provides on the exception of copyright law related to teaching, which reads as follows:

"It shall be a matter for legislation in the countries of the Union, and for special agreements existing or to be concluded between them, to permit the utilization, to the extent justified by the purpose, of literary or artistic works by way of illustration in publications, broadcasts or sound or visual recordings for teaching, provided such utilization is compatible with fair practice".

Before discussing further Article 10(2) of the Berne Convention, it is important to note the effect of the Berne Convention to countries before and after TRIPS Agreement. By the end of the Uruguay Round in April 15, 1994, the Berne Convention was perceived as inadequate for addressing the needs of their business sectors in the "post-industrial era" or "information age" by the developed country contracting parties of GATT 1947 (Abbot, 2003, p. 11). TRIPs 1995 was considered a more comprehensive international agreement on copyright and intellectual property. Yet, the TRIPs Agreement require contracting states to comply 
with most of the provisions of the Berne Convention, irrespective of whether the country is a signatory to that Convention. The effects of the TRIPs Agreement on countries also vary based on the degree to which these countries had established a domestic system of copyright protection prior to becoming WTO members. Developing countries such as Hong Kong, Indonesia, Singapore, and Guatemala that were not parties to the Berne Convention prior to becoming WTO members are now required to commit to a higher level of domestic reform with regard to the copyright legislation in their country.

\section{Copyright Exception for Teaching Purposes}

Analyzing Article 10(2) of the Berne Convention, this provision reserves the right whether to allow or disallow utilization of works for teaching purposes to the discretion of member countries. This provision is not mandatory (Ricketson, 2003) due to the words "It shall be a matter for legislation in the countries". Hence individual countries have the discretion whether to make copyright exceptions relating to teaching purposes or not. The matter is left for national legislation or for bilateral agreements between Union members to decide on (Ricketson \& Ginsburg, 2006). However, in the event a country wishes to make copyright exceptions for teaching purposes in its national law, it has to adhere to the limits set out under Article 10(2) of the Berne Convention.

The wording of Article 10(2) of the Berne Convention is purposely couched to be open and flexible, so as to allow national lawmakers to take advantage of its flexibility and to apply the scope of the teaching exception according to their individual circumstances (Xalabarder, 2009). A flexible interpretation of the word "utilization" in Article 10(2) should grant a broad range of rights, namely reproduction, adaptation, translation, distribution, communication and making available to the public, and whatever rights are determined by national legislation (Wahid, 2011). A liberal approach of interpreting and implementing the copyright exceptions (Wahid, 2011b) will aid any act of the copying, distributing or communicating of copyrighted materials to students, as it falls under the copyright exceptions. This exception can also be applied for the purpose of teaching in both public and private educational institutions. Article 10(2) also covers a broad range of works that may be used under the teaching exception. This includes literary works, such as textbooks, journals, or artistic works such as photographs and broadcasts as well as sound and visual recordings.

Article 10(2) further requires the fulfilment of certain conditions, namely "justified by the purpose" and "compatible with fair practice", which are however worded in general terms and necessitate further interpretation by the courts. Hence, the provision still allows for national law to take advantage of the inherent flexibilities. Thus, it is for national law to determine the exempted use of works for teaching purposes, within the limits of Article 10(2) (Xalabarder, 2007). Nonetheless, the interpretation of 'teaching' under Article 10(2) carries some degree of risk, as it limits the exceptions to only formal educational activities only. In short, the exceptions provided under the international agreements are couched in 
general terms, so as to pose as guidance and a yardstick for member countries to make laws that suit their needs and circumstances, yet it is questionable whether these generous provisions are fully utilized to their maximum potential by individual countries.

\section{Countries Different Approach to Copyright Exceptions}

National laws supplementing the international treaties differ widely between individual countries (Sterling, 2003) particularly on the extent of limitations adopted for the benefit of education (Crews \& Ramos, 2004; Guibault, 2003; Xalabarder, 2004). This occurs when national legislatures retain a great measure of discretion in the way in which they interpret and implement their international copyright obligations (Tawfik, 2005). These variations are understandable, recognized and even encouraged by the provisions of the international and regional instruments allowing countries to make their own decisions, within certain parameters, so as to suit the individual countries diverse political, economic, social and cultural interests and needs.

By analysing the similarities and differences in the copyright exceptions relating to teaching purposes between the UK, Australia and Malaysia, which predominantly consumes educational materials, an interesting finding was found. Australia provides the most flexible copyright exceptions for teaching purposes. The Australian Copyright Act 1968, taking into account amendments up to Act No. 113 of 2008, has an open fair dealing provision for study purposes, allows reproduction, multiple reproductions, inclusion of works in collections, and the right to communicate works subject to several conditions (Wahid, 2011). The scope of purposes allowed under the Australian exception also broadly covers study and instruction, and commercial and non-commercial purposes. The teaching exceptions benefit both teachers and students, and they also cover various types of work useful for teaching activities, including works in new formats. Australia further provides for residual exceptions for the purpose of education. Seemingly, careful thought and consideration have been made in outlining the elaborate provisions regarding exceptions for teaching purposes in the Australian law.

Comparatively, the United Kingdom Copyright Design and Patent Act 1988 are more organized in the set up of its copyright exceptions for educational purposes, compared to Australia. In terms of allowing use of copyright works in teaching for commercial purposes, the UK is similar to Australia, as it permits the same, subject to fair dealing. However, the UK is less flexible in its exception, as it does not allow the right of communication, which is increasingly important in teaching activities, and does not extend the exception to new formats (Wahid, 2011). "Communication" here refers to making copyright material available online, or to electronically transmitting copyright material, while "making available" can include putting material on an intranet, and "electronic transmission" includes email, streaming or electronic reticulation (Browne, 2009, p. 453). 
Surprisingly, Malaysia Copyright Act 1987, No.332, Act A1139/2002, despite being a developing country, which may require easy access to materials for teaching purposes, turns out to have the narrowest copyright exception for teaching purposes. It does not permit the right of communication nor allow any reproduction or multiple reproductions for teaching purposes at all. It merely allows the "inclusion" of works for teaching, which is limited in many ways. The scope of purpose allowed is also confined to "teaching", which is narrower than the term "instruction" used in the UK and Australia. It is also silent on the beneficiaries that may apply the exception. Similar to the UK, Malaysia also has not included new formats of works that may benefit from the teaching exception. This has left users in teaching activities at a disadvantage.

In order to make full use of the vibrancy of information communication technology for the pursuit of education, it is essential that the existing provisions be refined. Ida Madieha (2002) suggests the following revisions:

(i) To allow others who facilitate students with providing course materials such as librarians, lecturers and educational institutions to do the copying on behalf of the students.

(ii) To expand "showing or playing to the public" exception to cover transmission of online material or transmission by digital means.

(iii) To expand the exception for use of work for educational purposes to not only those used for illustration, but also for materials directly related and of assistance to the teaching.

(iv) The provision on 'illustration' be broadly interpreted to allow a students to view a work asynchronously at a time suitable for them. Such use must not be dependent on physical classroom.

(v) Permitting transmission to be made to students officially enrolled in the course regardless of their physical location.

(vi) Allow the downloading and retention of materials by students

(vii) Allow the educational institutions to upload works onto a server.

(viii) To read the library use provision to cover any possible electronic use of a work in order to permit effective research and gathering and organising information.

In a 2008 study conducted by Consumer International, it was found that copyright is not the sole factor to the lack of access to educational materials in Malaysia. Beside copyright, there are a host of other factors including:

(i) Restrictive terms of licensing agreements. Access to foreign databases is facilitated through licensing agreements. These agreements which contain terms which are favourable to the database producers further restrict usage of the databases.

(ii) Unwillingness to grant reprint licences to local publishers. As a result, books reprinted as local editions are pretty limited and the market depends on imported books which are rather pricy. 
(iii) Lack of clear guidelines and effective copyright clearance policy for multiple classroom reproduction. This has perpetuated the practice of photocopying in Malaysia and the general lack of respect of intellectual property.

(iv) Lack of clear guidelines on library usage hampers optimization of interlibrary loan usage and dissemination of unpublished research results in the form of students' dissertation and theses.

(v) Other industry practices such as control over parallel imports and the supply of international editions.

Consumer International calls for the reform of the copyright law to ensure that all the flexibilities available to Malaysia under the Berne Convention and other important copyright treaties including the WIPO Copyright Treaty, are availed of. This requires a comprehensive study of the existing provisions vis a vis the flexibilities granted under the Treaties as well as comparing notes with other country practices.

Maintaining the right balance is key in any national copyright policy. Yet achieving this is not easy as copyright policies are often hijacked by other external pressures such as trade liberalisation. Khaw (2004) questions whether such balance still hold and in whose favour should the balance be tilted. She points of two apparent examples with regards to new technologies. Firstly, there are no express provisions for any permitted acts in relation to anti-circumvention measures. As a result, it is not possible for the librarian or anybody from the academic community to bypass the antic-circumvention measures to make acquisition decision. Secondly, with respect to computer programs, there is no provision for reverse engineering or decompilation for the purpose of correcting errors or making interoperable programs or products. Both areas are crucial for the academic community.

In short, the UK and Australia, took into account the needs of the owners of copyright work, as well as the needs of teachers and students to access and use the work for learning purposes. While UK is a little restrictive on the rights granted for instructional purposes, Australia provides more flexible exceptions, granting more rights, covering more aspects of works, taking into account the new changes in educational delivery, and allowing a wider range of beneficiaries, but at the same time clearly limiting the extent or proportion that can be used under the teaching exceptions. Malaysia, being predominantly a user of educational materials, seems to have a narrow provision for teaching purposes, which is in stark contrast to its interest in having greater access to educational materials.

\section{Lessons to be Learned}

In today's globalized world, knowledge and information are no more confined to a single jurisdiction and can be disseminated around the world easily through the Internet and (Perlmutter, 2002). Companies that produce and distribute content are often multinational, or at least operate their businesses across national borders. In respect of research and education, collaborative projects and research cooperation between higher education 
institutions in various countries have constantly been designed, funded and developed. Occasionally, these educational activities are restraint as a result of difficulties in accessing works due to copyright restrictions which is different from one country to another. Although international copyright law allows certain exceptions and limitations to copyright protection for the purpose of education, its implementation is largely dependent on the discretion and interpretation of individual countries according to their needs and circumstances. Hence, different countries' laws would affect each other, as they deal with intersectional issues (Perlmutter, 2002). The copyright balance, and its effect on incentives and the public interest, can no longer be confined to a purely domestic sphere.

The above discussion shows that individual countries have all couched their copyright exceptions relating to teaching purposes in various ways. The relevant provisions in the UK, Australia and Malaysia appear similar since all three countries permit exceptions for teaching or instruction purposes, possibly because the importance of education is well recognized in all countries, despite the different economic, social and political backgrounds. Such was true even before copyright exceptions were firstly negotiated in the international treaties; most countries already had copyright exceptions relating to education.

The existence of similarities between the UK, Australia and Malaysia copyright law are also because Australia and Malaysia were both former colonies of the British Empire, and so English law has a great deal of influence in both countries. History shows that the UK Imperial Copyright Act of 1911 was enforced in the colonial lands of Australia from $1^{\text {st }}$ July 1912, repealing all previous legislation. This British Act remained in force until it was repealed by the current version of the Commonwealth Copyright Act in 1968. Since then, the Copyright Act 1968 has been consistently revised in response to various technological and industrial developments without much change with regards to its exceptions. This continues until the Copyright Law Committee appointed in 1974 ("the Franki Committee"), in reviewing Australian Copyright Law amongst others, refers to earlier reports on copyright including the Report of the Copyright Committee 1951 of the UK (CMD 8662) ("the Gregory Committee"), which recommended most of the provisions now contained in the Copyright Act 1956 of the UK (Davison, Monotti, \& Wiseman, 2008). The copyright law in Malaysia is also not homegrown, and mainly originate from British colonization; it was further shaped by the influence of other developing countries and by international agreements. However, it seems that not much research has been conducted as compared to Australia to examine the implications of copyright law for Malaysian development.

On the other hand, differences seem to exists with respect to the detailed scope of the purposes allowed, the beneficiaries that may use the exception, the types of work covered by the exception as well as further details in determining what constitutes fair dealing. These differences may reflect each country's level of engagement with the matter; Australia has conducted numerous inquiries and studies into many aspects of copyright law, including the impact of reprographic reproduction on copyright law in Australia, examining the exceptions to the exclusive rights of copyright owners (Simplification of Copyright Act: 
Part 1, 1998), and the status of Crown Copyright (2005). This latter was made through the Copyright Law Review Committee (CLRC), an advisory body for copyright reform, which began its deliberations in 1983. Studies were also conducted by that Committee at the time when Australia was a net importer of copyright works, and thus it was aware that no radical steps were to be taken; in commencing the review, the Copyright Law Committee on Reprographic Reproduction (1976, p. 9) reminded itself that the primary purpose of copyright law was:
"...to give to the author of a creative work his just reward for the benefit he has bestowed on the community and also to encourage the making of further creative works. On the other hand, as copyright in the nature of a monopoly, the law should ensure, as far as possible, that the rights conferred are not abused and that study, research and education are not unduly hampered".

This shows that Australia has always been mindful of the effect of copyright law on the public interest, as the country was a net importer of copyright works before rising to being a net producer of copyright works. In recent years however, the Australian provision have been narrowed reflecting the standards set by international agreements and multilateral treaties, and the US - Australia Free Trade Agreement (Seng, 2009).

Similarly in the UK, various studies have been conducted into how to manage the issue of the reprographic copying of copyright works for the purpose of education, pursuant to the development of photocopying in the 1970s (Piccioto, 2002). The Malaysian context, however, is different in the sense that people have only recently become aware of the concept of copyright, and ignorance about any exceptions and limitations to copyright is widespread. Furthermore, few studies have been conducted on the question of the suitability of the country's copyright law or in framing the most appropriate exceptions to copyright needed in the Malaysian context (Wahid, 2011). Malaysian copyright law is merely a simple adaptation of the law of the former colonial power, without much consideration of the matter. Its copyright exceptions to education, is very simple and fails to address many important aspects. Compared to UK that also have restrictive copyright provisions, Malaysia does not provide much alternatives or resources for users such as a sufficient licensing system to monitor the conflict of interest between the owners and the users, leaving users with few options, resulting in widespread copyright abuse.

The lack of exceptions for educational use has been the subject of contention during the most recent copyright revision in lieu of knowledge as the crucial seeds for knowledge economy. During the revision in 2009-2010, several proposals were forwarded with the view of optimizing the copyright exception to the fullest. Most of the proposals however were short-lived. The surviving proposals resulted in the refinement of the law which is later passed as the Copyright Amendment Act 201.Therevisions are: 
i) Fair dealing for research purposes. Previously, this is only confined to non- profit research. With the new position, the objective of the research will no longer be relevant.

ii) The provision relating to the recording made for the use of schools, universities or educational institutions under section 13(2)(g) of the Copyright Act 1987 has been expanded to cover any reproduction made for the use of these institutions. The new provision presumably will cover all academic usage of copyright materials in academic institutions including the uploading of relevant materials for online digital education. Will this also cover multiple classroom reproduction? Presumably yes.

More fundamentally, the US four fair use factors have been incorporated as a yardstick to determining whether a particular use falls within the 'fair dealing' exception. Such move is rather radical as it is always thought that the fair use concept which is open-ended is the sharp contrast to fair dealing which is tied up to the purposes mentioned in the provision. It would be interesting to see how the Malaysian courts play around with US jurisprudence in exploring the scope of fair dealing in Malaysia.

\section{Conclusion}

The issue of exceptions to copyright protection in respect of teaching or education play an important role in balancing the owners' rights and the interests of the public in accessing information. In the rapid development of ICT, knowledge and information is increasingly used as commodities that can be controlled, bought or sold. The price of educational materials rises and it becomes more expensive to subscribe or access quality or authoritative information from journals, books and internet service providers, etc. Such practice is supported by copyright law despite the fact that the original purpose of copyright law is not so much to protect the interests of the authors/creators, but rather to promote the progress of science and the useful arts. An appropriate copyright exception is even more important when no efficient licensing system, nor means of governing or guiding the process of negotiating the owner's right against the user's interest, is readily available.

A balanced perspective in terms of copyright and its impacts to others is pertinent to avoid any unnecessary barriers in accessing information and knowledge for the benefit of the public (Wagner \& Karen, 1998). Tighter regulation, and merely adopting and relying on the models of other countries as well as international treaties, will not benefit the country or change the people into respecting the law. It is recommended by the United Nations that intellectual property rights "be implemented in such a way as to promote dynamic competition through the acquisition and local development of technology in an environment that is conducive to growth" (Smith, 1999, p. 98). Dynamic competition cannot be achieved through stringent rules that hinder access to knowledge and learning materials. The regulatory system should preserve the values on which the copyright system was built, which is to encourage learning. Hence it should not hinder access to knowledge, but instead actively promote it (Geiger, 2006, p. 373). 
Both protection and access are twin components of the public interests (Okediji, 2006). Access is important to facilitate the dissemination of knowledge, thus resulting social welfare gains, and for the benefit of downstream creators who rely on the availability of a robust public domain from which to draw resources for productive ends. In other words, access plays an instrumental role in supporting public domain which will in turn be the source of future production of knowledge. Ideally, of course, it has to have 'public interest' as the overriding exceptions to the exclusive rights of the copyright owners. In this respect, she suggested that countries institutionalize the limitations and exceptions in the international copyright system. Some exceptions should be allowed without compensation such as personal use, use for criticism or review, educational purposes, reproduction by press, ephemeral recording, libraries, limitation involving person with disabilities and computer programs and interoperability. She further cautions the impact of FTAs on limitations and exceptions. Most FTAs contain TRIPS plus provisions which further curtail the existing copyright exceptions. In order to ensure that the existing flexibilities are diluted by the FTAs, she suggested the establishment of an international treaty. This treaty should contain the minimum limitations and exceptions that cannot be derogated.

Considering various efforts for intellectual property to become a tool for economic growth, it is important for countries to address the issue of access to information for the purpose of education which considers the interests of both copyright owners and users. Moreover, one should not take for granted the shared responsibility (Sithigh, 2006, p. 412) in supporting true education taking place in educational institutions which is considered as a basic human right for all.

In this respect, a lot needs to be done still in Malaysia. As the recent copyright reform cycle shows, there should be more push towards this from the copyright users especially among the academic communities and the librarians. Such need is even more crucial as Malaysia is at the final phase of two trade pacts, the FTA with the EU and the Trans-Pacific Partnership Agreement.

\section{References}

Abbot, F. (2003). Course on dispute settlement in international trade, investment and intellectual property. New York: UNCTAD.

Altbach, P., Reisberg, L., \& Rumbley, L. (2009). Trends in global higher education: Tracking an academic revolution. France: UNESCO.

Crews, K. D., \& Ramos, J. (2004). Comparative analysis of world copyright law: Issues for university scholarship. Paper presented at the Copyright Management for Scholarship Conference, Zwolle, Netherlands. Retrieved from http:/copyright.surf.nl/copyright/ files/International_Comparative_Chart_Zwolle_III_rev071306.pdf 
Davison, M. J., Monotti, A., \& Wiseman, L. (2008). Australian intellectual property law. Melbourne: Cambridge University Press.

Fisher, W., Palfrey, J., McGeveral, W., Harlow, J., Gasser, P., \& Jaszi, P. (2006). The digital learning challenge: Obstacles to educational uses of copyright material in the digital age. Harvard University: Berkman Center for Internet and Society.

Garnett, K., James, J. R., \& Davies, G. (1999). Copinger and Skone James on copyright (14th ed.). London: Sweet \& Maxwell.

Geiger, C. (2006). Copyright and free access to information: For a fair balance of interests in a globalised world. European Intellectual Property Review, 28(7), 366-373.

Guibault, L. (2003). The nature and scope of limitations and exceptions to copyright and neighbouring rights with regard to general interest missions for the transmission of knowledge: Prospects for their adaptation to the digital environment. e-Copyright Bulletin. Retrieved from http://portal.unesco.org/culture/en/files/17316/ 108747977511_guibault_en.pdf/1_guibault_en.pdf

Ida Madieha Abdul Ghani Azmi. (2002). Digital technology, copyright and education-The Malaysian perspective. IIUM Law Journal, 10(1), 13-40.

Ida Madieha Abdul Ghani Azmi. (2008). Project on copyright and access to knowledge. Country Study - Malaysia. Consumer International Malaysia.

Khaw, L. T. (2004). Copyright law in Malaysia: Does the balance hold? Journal of Malaysian and Comparative Law, 2.

Matsuura, K. (2009). The future of knowledge acquisition and sharing. Paper presented at the UNESCO Future Forum on Knowledge Acquisition and Sharing. Retrieved from unesdoc.unesco.org/images/0018/001824/182432e.pdf

Okediji, R. L. (2006). The international copyright system: Limitations, exceptions and public interest considerations, for developing countries. UNCTAD-ICTSD Project on IPRs and Sustainable Development. Issue Paper No 15. Switzerland: ICTSD \& UNCTAD.

Perlmutter, S. (2002). Participation in the international copyright system as a means to promote the progress of science and useful arts. Loyola of Los Angeles Law Review, $36,323-335$.

Picciotto, S. (2002). Defending the public interest in TRIPs and the WTO. In P. Drahos \& R. Mayne (Eds.), Global intellectual property rights: Knowledge, access and development. Palgrave. 
Ricketson, S. (2003). WIPO study on limitations and exceptions of copyright and related rights in the digital environment (No. SCCR/9/7). Geneva: World Intellectual Property Organization.

Ricketson, S., \& Ginsburg, J. (2006). International copyright and neighbouring rights: The Berne convention and beyond (2nd ed.). London: Oxford University Press.

Sandy, N. (2004). Practical copyright for information professionals: The CILIP handbook. London: Facet Publishing.

Seng, D. (2009). WIPO study on the copyright exceptions for the benefit of educational activities for Asia and Australia. Geneva: WIPO. Retrieved from http://www.wipo. int/meetings/en/doc_details.

Sithigh, D. M. (2006). Students contributions to academic values. Higher Education Europe, 31(4), 409-413.

Smith, M. W. (1999). Bringing developing countries' intellectual property laws to TRIPs standards: Hurdles and pitfalls facing Vietnam's efforts to normalize an intellectual property regime. Case Western Reserve Journal of International Law, 31(1).

Sterling, J. A. L. (2003). World copyright law. London: Sweet \& Maxwell.

WIPO. (1971). Records of the intellectual property conference of Stockholm, June 11-July 14, Vol.I \& II

Tawfik, M. (2005). International copyright law: W[h]ither use rights? In M. Geist (Ed.), In the public interest: The future of canadian copyright law. Ontario: Irwin Law Inc.

UNESCO. (2009). Retrieved from http://portal.unesco.org/education/

Wagner, \& Karen. I. (1998). Intellectual property: Copyright implications for higher education. The Journal of Academic Librarianship, 24(1), 11-19.

Wahid, R. (2011). Exploring flexibilities within the international copyright system for teaching, research and study (Unpublished doctoral dissertation). Norwich Law School, East Anglia University.

Wahid, R. (2011b). The fairness of 'stealing' knowledge for education. Journal of International Commercial Law and Technology, 6(2), 86-95.

Xalabarder, R. (2004). Copyright exceptions for teaching purposes in Europe. IN3:UOC. (Working Paper Series: WP04-004). Retrieved from http://www.uoc.edu/ 
Xalabarder, R. (2007). On-Line teaching and copyright: Any hopes for an EU harmonized playground? In P. Torremens (Ed.), Copyright law: A handbook of contemporary research. UK: Edward Elgar Publishing.

Xalabarder, R. (2009). Study on copyright limitations and exceptions for educational activities in North America, Europe, Caucasus, Central Asia and Israel. Geneva: WIPO. Retrieved from http://www.wipo.int/meetings/ 
